\title{
Influence of Breastfeeding and Complementary Feeding on Serum and Erythrocyte Zinc Levels in Preterm and Term Infants: A Cross-sectional Study
}

Talita Rodrigues Azevedo e Silva

Federal University of São Paulo

Anna Caroline Pereira Vivi

Federal University of São Paulo

Fernando Luiz Affonso Fonseca

Faculdade de Medicina do ABC

Cibele Wolf Lebrão

Hospital Municipal Universitário de São Bernardo do Campo - HMU

Maria Wany Louzada Strufaldi

Federal University of São Paulo

Roseli Oselka Saccardo Sarni

Faculdade de Medicina do ABC

Fabiola Isabel Suano-Souza ( $\square$ suano.souza@unifesp.br)

Federal University of São Paulo

\section{Research Article}

Keywords: Zinc, preterm infant, food intake, infants, anthropometry

Posted Date: May 17th, 2021

DOl: https://doi.org/10.21203/rs.3.rs-514609/v1

License: (9) (i) This work is licensed under a Creative Commons Attribution 4.0 International License.

Read Full License 


\section{Abstract}

Background: Zinc is an important micronutrient involved in cell division, growth, and immune system function. Most studies evaluating the nutritional status related to zinc and prematurity were conducted with hospitalized preterm infants. These studies show controversial results regarding the prevalence of deficiency, clinical implications, and the effect of zinc supplementation on mortality, infectious diseases, and growth in these groups. This study aimed to compare serum and erythrocyte zinc levels in a group of preterm and term infants during complementary feeding and related the zinc levels to dietary intake, and current nutritional condition in both groups.

Methods: Cross-sectional study with 43 preterm infants (24 to 33 weeks) aged 9-24 months (mean: $14.3 \pm 6.4$ months), compared with 47 term healthy infants. Data collected: socioeconomic status and maternal health during pregnancy, dietary history, anthropometry (weight, height, and head circumference), and current dietary intake. Laboratory tests: blood count, serum and erythrocyte zinc concentrations, and C-reactive protein.

Results: Males predominated (24, or $55.8 \%)$ in the preterm group; the mean birth weight was $1,245 \pm 381.7$ grams. Serum zinc levels $<65 \mu \mathrm{g} / \mathrm{dL}$ and anemia were observed in four preterm (5.1\%) and four term infants (5.3\%), respectively. No infant had erythrocyte zinc $<40 \mu \mathrm{g} / \mathrm{gHb}$. The variables independently associated with serum zinc levels were breastfeeding at the time of evaluation $(20.11 \mu \mathrm{g} / \mathrm{dL} ; 95 \% \mathrm{Cl} 9.62$ to $30.60 ; p<0.001)$ and late (4-7 months) introduction of complementary feeding $(6.6 \mu \mathrm{g} / \mathrm{dL} ; 95 \% \mathrm{Cl} 5.3$ to $11.4 ; p<0.001)$. Breastfeeding was also independently and directly associated with erythrocyte zinc levels (18.8 ug/dL; $95 \% \mathrm{Cl} 3.7$ to 33.8; $\mathrm{p}=0.015$ ).

Conclusions: No difference was observed in the nutritional status related to zinc between preterm and term infants during complementary feeding. Serum and erythrocyte zinc levels were influenced by breastfeeding and the onset of solid foods.

\section{Background}

Hidden hunger is a type of malnutrition associated with a lack of micronutrients, and clinical signs appear when the deficiency is at an advanced stage. The World Health Organization (WHO) reports that more than two billion people worldwide suffer from 'hidden hunger', and the main micronutrients related to this condition are iron, zinc, vitamin A, iodine, and folic acid [1, 2].

Zinc is an important micronutrient involved in cell division, growth, and immune system function. This micronutrient participates as a constituent of more than 300 metalloenzymes, influences more than two thousand transcription factors, and participates in the regulation and expression of hundreds of genes [3, 4].

Zinc deficiency is a public health problem in low- and middle-income countries [3], and the measurement of plasma/serum concentration is the main indicator used to assess their deficiency [4]. A meta-analysis 
including studies with national data on zinc deficiency found alarming deficiency levels (> $20 \%$ of the population under five years old) in 23 of the 25 countries assessed [5].

The classic clinical zinc deficiency manifestations such as irritability, diarrhea, stunting, and enteropathic acrodermatitis appear in moderate and severe deficiency. However, subclinical deficiency is already associated with impaired immune response and cell replication, increasing the susceptibility to infectious and impaired the growth in children $[3,5]$.

Zinc supplementation in term infants in non-developed countries younger than six months [6] and from 6 to 12 months of life [7] was related to slight improvement in growth and lower prevalence of the diarrheal disease. Preterm newborns (PTNB) are considered at risk for zinc deficiency due to lower reserves, accelerated postnatal growth, immature gastrointestinal tract, diseases developed during hospitalization, and lower food supply of this micronutrient $[8,9]$.

Most studies evaluating the nutritional status related to zinc and prematurity were conducted with hospitalized preterm infants $[10,11]$ or small for gestational age $[12,13]$. These studies show controversial results regarding the prevalence of deficiency, clinical outcomes, and the effect of zinc supplementation on mortality, infectious diseases, and growth in these groups. Few studies have evaluated the zinc-related nutritional status in moderately and extremely preterm infants after hospital discharge and during complementary feeding [14-16].

This study aimed to compare serum and erythrocyte zinc levels in a group of preterm and term infants during complementary feeding and related the zinc levels to dietary intake, and current nutritional condition in both groups.

\section{Methods}

\section{Study design}

A cross-sectional study was carried out from 2018 to 2019 with 43 preterm infants (Preterm Group, gestational age from 24 to 33 weeks), with age 9 to 24 months, at the follow-up clinic of the Hospital Municipal Universitário de São Bernardo do Campo (HMU-SBC). The comparison group consisted of 47 healthy term infants (Term Group), adequate for gestational age and weighing more than 2,500 grams, of the same age, in follow-up at the Primary Care Health of the same city.

The HMU-SBC adopts the Kangaroo Method. The place is accredited as a Baby-Friendly Hospital and is a reference for high-risk pregnancies in the city. About $14 \%$ of births are preterm, and the breastfeeding rate for preterm infants at hospital discharge is $82 \%$. Preterm newborns with gestational age $<34$ weeks or birth weight $\leq 1,500$ grams are referred to and monitored at the outpatient clinic up to the age of six by a multidisciplinary team consisting of a pediatrician, a psychologist, a social worker, and a physiotherapist. The follow-up is complementary to that performed by the Primary Care Health. 
There were excluded from the sample infants with severe malformations (cardiac, abdominal wall, musculoskeletal, and central nervous system defects), genetic syndromes, chronic non-progressive encephalopathy, oxygen-dependent children, those who did not feed exclusively orally, who had intolerance and food allergies, who were unable to provide telephone contact for invitation to be included in the study, and whose family refused to participate. A total of $43 / 69(62.3 \%)$ and $47 / 78(60.2 \%)$ of the eligible infants in the preterm and term groups, respectively, were included in the final study sample.

The Research Ethics Committee of Universidade Federal de São Paulo approved the study under Opinion $N^{\circ}$ 2.937.127 and we confirm that all methods were perfomed in accordance with the Declaration of Helsinki. The children's legal guardians signed the informed consent form after the interview and clarifications by the researchers regarding the study's steps and procedures.

\section{Collected data}

\section{General informations}

We obtained information on socioeconomic status and maternal health during pregnancy, such as maternal age, parental schooling, per capita income, pre-gestational nutritional condition, and diseases reported during pregnancy.

Data were collected on weight, height, head circumference, gestational age, causes of prematurity, and Apgar score regarding birth. The gestational age was calculated, firstly, according to the date of the last menstruation, secondarily, the ultrasonography data of the first trimester was adopted or the subjective evaluation of the newborn [17].

Birth weight was used to evaluate the adequacy for gestational age using the reference proposed by INTERGROWTH-21 [18]. We considered small (SGA), adequate (AGA), and large (LGA) when the birth weight for gestational age was below the $10^{\text {th }}$ percentile, from the $10^{\text {th }}$ to $90^{\text {th }}$, and above $90^{\text {th }}$, respectively.

\section{Anthropometry}

The principal investigator obtained all anthropometric and body composition measurements. At the time of the evaluation, weight data were measured on a digital, platform-type scale graduated in grams, with the infant undressed and without diapers. Height was measured with a horizontal stadiometer graduated in millimeters; head and arm circumference with an inextensible measuring tape; and the tricipital and subscapular skinfolds with a calibrated Langer ${ }^{\circledR}$ type adipometer [19].

These measures were used to calculate anthropometric indicators as Z-scores of body mass index (BMIZ), height/age (HAZ) and head circumference/age (HCZ), through the WHO Anthro v.3.2.2. The 
cutoff points used for the classification were those proposed by the World Health Organization [20]. The corrected age of 40 weeks was used to calculate anthropometric indicators for preterm infants.

\section{Food consumption}

Information on type and duration of breastfeeding (exclusive and total), use of infant formulas and whole cow's milk, age at onset and sequence of introduction of complementary, and iron supplementation frequency and dose were collected.

Three 24-hour recalls were applied to assess food intake, with a maximum interval of 15 days between them. The estimated dietary intake was assessed by averaging the intake values of each nutrient in the recalls available for each infant. The calculation was performed using the DietWin ${ }^{\circledR}$ program, which uses the food composition tables proposed by the United States Department of Agriculture [21] and the Brazilian Food Composition Table [22].

Three, two, and one 24-hour recall were available in $24(26.7 \%), 16(17.7 \%)$, and $45(50 \%)$ of the infants included in the study. They were used to calculate total daily ditary intake of energy (kcal and $\mathrm{kcal} / \mathrm{kg}$ ), protein $(\mathrm{g}$ and $\mathrm{g} / \mathrm{kg}$ ), iron $(\mathrm{mg})$ and zinc $(\mathrm{mg})$. The main meals were defined as food consumed at lunch or dinner per the traditional Brazilian eating habits, in general, rice, beans, meats, and vegetables [23] and complementary feeding such as the combination of main meals and snacks.

The consumption of infant formula and whole cow's milk was not added to the calculation of complementary feeding to enable comparison between breastfed and non-breastfed infants. We could not quantify the volume of milk consumed in breastfed children, but the number of times (frequency) that the child received breastfeeding during the day was recorded.

\section{Laboratory tests}

A total of $8 \mathrm{ml}$ of blood was collected by peripheral venipuncture with a fasting period of 3 hours and in the morning. The blood aliquot was divided into tubes for collecting metals (Vacuette tube ${ }^{\circledR}$, without additive), dry tube, and EDTA tube.

The material was immediately transported to the Clinical Analysis Laboratory of the CU-FMABC, where the sample preparation, laboratory analysis, and storage were carried out. Samples that were not analyzed immediately were stored in a freezer at $-80^{\circ} \mathrm{C}$.

The blood count was performed with the multi-parameter automated hematology analyzer (Cell-Dyn Ruby) using the Multi-Angle Polarized Scatter Separation technology and laser flow cytometry. Anemia was defined by the presence of hemoglobin $(\mathrm{Hb})$ below $11 \mathrm{~g} / \mathrm{dL}$ [24]. The ultra-sensitive C-Reactive Protein (CRP) was measured by turbidimetry. 
Serum and erythrocyte zinc levels were determined by the inductively coupled plasma mass spectrometry method (ICP-MS). Red cell lysis was performed with phosphate buffer. The reference values adopted for serum and erythrocyte zinc were $65 \mu \mathrm{g} / \mathrm{dL}$ [4] and $40 \mu \mathrm{g} / \mathrm{g}$ hemoglobin $(\mu \mathrm{g} / \mathrm{gHb})$ [25], respectively.

\section{Statistical analysis}

The collected data were tabulated and consolidated in Excel spreadsheets (Office Microsoft $®$ ), and the analyses were performed in the statistical package SPSS 25.0 (IBM $\left.{ }^{\circledR}\right)$. Categorical variables were presented as absolute numbers and percentages and compared with the Chi-square test. The distribution of continuous variables was assessed using the Shapiro-Wilk test, histograms, and Kurtosis values. The variables with parametric distribution were presented as mean \pm standard deviation and compared by the Student's t-test for independent variables. Variables with nonparametric distribution were presented as medians and interquartile ranges (p25 - p75) and compared with the Mann-Whitney test.

The Enter linear regression method was adopted for the multivariate analysis, using serum and erythrocyte zinc as dependent variables. The independent variables were included in the model after the analysis of collinearity, which showed a statistically significant difference between the groups and those with clinical relevance. A significance level of $5 \%$ was adopted in all analyses.

Employing a-bidirectional $=0.05$ and $\beta=0.20$ allowed the included sample (45 infants per group) to detect a difference of $10 \mu \mathrm{g} / \mathrm{dL}$ of serum zinc between the groups (standardized magnitude of effect of 0.6). For this calculation, we used data from the paper published by Cho et al., 2019 [13], which found mean and standard deviation in serum zinc levels of $81.4 \pm 18.7 \mu \mathrm{g} / \mathrm{dL}$ in a group of preterm infants.

\section{Results}

Table 1 shows the general characteristics of the studied infants. Males predominated in the preterm group, with 24 (55.8\%); the mean birth weight, gestational age, and corrected age were 1,245 \pm 381.7 grams, $29.9 \pm 2.3$ weeks, and $14.3 \pm 6.4$ months, respectively. In these, $13(30.2 \%), 11(25.6 \%)$, and 29 $(67.4 \%)$ were small for gestational age, extremely low weight $(<1000 \mathrm{~g})$, and were born less than 32 weeks. 
Table 1

General characteristics of infants, mothers, history and eating habits, current nutritional status, and inadequate hemoglobin and zinc levels

\begin{tabular}{|c|c|c|c|c|}
\hline Variables & & $\begin{array}{l}\text { Preterm group } \\
(\mathrm{N}=43)\end{array}$ & $\begin{array}{l}\text { Term group } \\
(\mathrm{N}=47)\end{array}$ & $P$-value \\
\hline \multicolumn{5}{|c|}{ General characteristics of infants } \\
\hline Gender & Male & $24(55.8 \%)$ & $20(42.8 \%)$ & $0.291^{1}$ \\
\hline Gestational age & Weeks & $29.9 \pm 2.3$ & $39.0 \pm 1.2$ & $<0.001^{2}$ \\
\hline Birth weight & grams & $1245 \pm 381.7$ & $3288 \pm 459$ & $<0.001^{2}$ \\
\hline Delivery type & Cesarean & $27(62.8 \%)$ & $23(48.9 \%)$ & $0.209^{1}$ \\
\hline Twinning & Yes & $4(9.3 \%)$ & $0(0.0 \%)$ & $0.002^{1}$ \\
\hline GA Classification & SGA & $13(30.2 \%)$ & $0(0.0 \%)$ & $<0.001^{1}$ \\
\hline Age (real) & Months & $16.7 \pm 6.3$ & $15.9 \pm 4.5$ & $0.493^{2}$ \\
\hline Age (corrected) & Months & $14.3 \pm 6.4$ & $15.9 \pm 4.5$ & $0.165^{2}$ \\
\hline \multicolumn{5}{|c|}{ Maternal characteristics } \\
\hline Maternal age & Years & $29.9 \pm 7.3$ & $29.4 \pm 6.8$ & $0.781^{2}$ \\
\hline Per capita income & Reais & $577.41 \pm 382.20$ & $731.44 \pm 455.9$ & $0.160^{2}$ \\
\hline Primiparous & Yes & $12(38.7 \%)$ & $17(37.0 \%)$ & $0.532^{1}$ \\
\hline \multirow[t]{2}{*}{ Supplementation } & Iron & $23(53.5 \%)$ & $29(61.7 \%)$ & $0.523^{1}$ \\
\hline & Folic acid & $22(51.2 \%)$ & $18(87.2 \%)$ & $<0.001^{1}$ \\
\hline \multirow[t]{4}{*}{ Pregestational BMI } & Malnutrition & $3(10.3 \%)$ & $1(2.4 \%)$ & \\
\hline & Eutrophy & $11(37.9 \%)$ & $20(48.8 \%)$ & $0.505^{1}$ \\
\hline & Overweight & $9(31.0 \%)$ & $12(29.3 \%)$ & \\
\hline & Obesity & $6(20.7 \%)$ & $8(19.5 \%)$ & \\
\hline \multicolumn{5}{|l|}{ Current eating habits } \\
\hline Breastfeeding & Yes & $8(18.6 \%)$ & $25(53.2 \%)$ & $0.001^{1}$ \\
\hline
\end{tabular}

Captions: GA (gestational age), SGA (small for gestational age), BF (Breastfeeding) and BMI (Body Mass Index). Significance level of the Chi-square ${ }^{1}$, t-Student ${ }^{2}$, and Mann-Whitney ${ }^{3}$ tests. 


\begin{tabular}{|c|c|c|c|c|}
\hline Variables & & $\begin{array}{l}\text { Preterm group } \\
(\mathrm{N}=43)\end{array}$ & $\begin{array}{l}\text { Term group } \\
(\mathrm{N}=47)\end{array}$ & $P$-value \\
\hline Infant formula & Yes & $17(39.5 \%)$ & $14(29.8 \%)$ & $0.379^{1}$ \\
\hline Cow milk & Yes & $28(65.5 \%)$ & $32(68.1 \%)$ & $0.825^{1}$ \\
\hline Iron supplementation & Yes & $28(65.1 \%)$ & $20(42.6 \%)$ & $0.037^{1}$ \\
\hline Iron dosage & $\mathrm{mg} / \mathrm{kg}$ & $1.6(1.2 ; 2.3)$ & $1.1(0.8 ; 1.3)$ & 0.008 \\
\hline \multicolumn{5}{|l|}{ Diet history } \\
\hline Exclusive BF & Yes & $30(69.8 \%)$ & $37(78.7 \%)$ & $0.346^{1}$ \\
\hline Exclusive BF time & Months & $3.0(2.0 ; 6.0)$ & $4.0(3.0 ; 6.0)$ & $0.430^{3}$ \\
\hline Total BF time & Months & $7.0(3.0 ; 9.2)$ & $11.3(6.0 ; 16.4)$ & $0.003^{3}$ \\
\hline Infant formula use & Yes & $34(79.1 \%)$ & $35(74.5 \%)$ & $0.628^{1}$ \\
\hline Onset of infant formula use & Months & $2.0(1.0 ; 3.0)$ & $2.0(0.0 ; 5.0)$ & $0.086^{2}$ \\
\hline Whole Cow's milk use & Yes & $14(32.6 \%)$ & $28(59.6 \%)$ & $0.012^{1}$ \\
\hline Onset of cow milk use & Months & $12.0(7.0 ; 16.5)$ & $8.0(7.0 ; 9.0)$ & $0.001^{3}$ \\
\hline Onset of fruits & Months & $7.0(6.2 ; 8.0)$ & $6.0(4.0 ; 6.0)$ & $<0.001^{3}$ \\
\hline First main meal & Months & $7.0(6.3 ; 8.0)$ & $6.0(5.0 ; 6.0)$ & $<0.001^{3}$ \\
\hline Family food & Months & $11.5(8.2 ; 12.0)$ & $10.0(9.0 ; 12.0)$ & $0.250^{3}$ \\
\hline \multicolumn{5}{|l|}{ Nutritional condition of infants } \\
\hline Height Z-score & $<-2 \mathrm{SD}$ & $11(25.6 \%)$ & $1(2.1 \%)$ & $<0.001^{1}$ \\
\hline \multirow[t]{3}{*}{ BMI Z-score } & $<-2 \mathrm{SD}$ & $5(11.6 \%)$ & $0(0.0 \%)$ & \\
\hline & -2 to $+1 S D$ & $38(88.4 \%)$ & $44(93.6 \%)$ & $0.016^{1}$ \\
\hline & +1 to $+3 \mathrm{SD}$ & $0(0.0 \%)$ & $3(6.4 \%)$ & \\
\hline \multicolumn{5}{|l|}{ Laboratory variables } \\
\hline Hemoglobin & $<11 \mathrm{~g} / \mathrm{dL}$ & $4(13.3 \%)$ & $4(9.1 \%)$ & $0.707^{1}$ \\
\hline Serum zinc & $<65 \mu \mathrm{g} / \mathrm{dL}$ & $2(6.3 \%)$ & $2(4.4 \%)$ & $0.554^{1}$ \\
\hline
\end{tabular}




\begin{tabular}{|c|c|c|c|c|}
\hline \multicolumn{2}{|l|}{ Variables } & $\begin{array}{l}\text { Preterm group } \\
(\mathrm{N}=43)\end{array}$ & $\begin{array}{l}\text { Term group } \\
(\mathrm{N}=47)\end{array}$ & $P$-value \\
\hline Erythrocyte zinc & $<40 \mathrm{ug} / \mathrm{Hb}$ & $0(0.0 \%)$ & & \\
\hline
\end{tabular}

The median length of hospital stay was 61 days (44.0 to 93 days). There was no statistical difference between the preterm and term groups concerning socioeconomic level, maternal age, pre-gestational maternal body mass index, and diseases reported during pregnancy.

Regarding the dietary history, exclusive/predominant breastfeeding was reported in $67(74.4 \%)$ of the evaluated infants. The median duration of exclusive breastfeeding was 3.0 months $[(2.0 ; 6.0)$ vs 4.0 (3.0; 6.0) months; $p=0.430]$ and total breastfeeding was 7.0 months $[(3.0 ; 9.2)$ vs 11.3 months $(6.0 ; 16.4) ; p=$ 0.003 ] in the preterm and term group, respectively (Table 1). The age of introduction of complementary feeding, using chronological age, was 7.0 months $(6.3 ; 8.0)$ in the preterm group and 6.0 months $(5.0 ; 6.0)$ in the term group $(p<0.001)$, with no difference regarding the sequence of the introduced foods (meat, eggs, fish, and family diet).

A lower percentage of preterm infants breastfeeding ( $18.6 \%$ vs. $53.2 \% ; p=0.001)$ was identified at the evaluation (Table 1). The median frequency of breastfeeding was $7.0(4.0 ; 8.0)$ and $5.0(3.5 ; 6.0)$ times a day $(p=0.295)$, in the preterm and term group, respectively. The median volume ingested of infant formula was $550 \mathrm{~mL} /$ day $(410.0 ; 675.0)$ vs. $600 \mathrm{~mL} /$ day $(545 ; 720.0)$ and for cow's milk $480 \mathrm{~mL} /$ day $(400.0 ; 560.0)$ vs. $520 \mathrm{~mL} /$ day $(220.0 ; 750.0)$; with no statistically significant difference between groups. Regular iron supplementation was more frequent in the preterm group $(65.1 \%$ vs. $42.6 \% ; p=0.037)$.

In the preterm group, a higher percentage of short stature was found ( $25.6 \%$ vs. $2.1 \% ; p<0.001)$, thinness $(11.6 \%$ vs. $0.0 \% ; p=0.016)$ and less overweight/obesity $(11.6 \%$ vs. $25.5 \% ; p=0.020)$ compared to the term group (Table 1). All anthropometric indicators showed lower mean values in the preterm group compared to the term group (Table 2). 
Table 2

Comparison of anthropometric and laboratory variables between preterm and term groups

\begin{tabular}{|lllll|}
\hline Variables & & $\begin{array}{l}\text { Preterm group } \\
(\mathrm{N}=\mathbf{4 3})\end{array}$ & $\begin{array}{l}\text { Term group } \\
\mathbf{( N = 4 7 )}\end{array}$ & P-value \\
\hline Body Mass Index $(\mathrm{n}=90)$ & Z-score & $-0.42 \pm 1.15$ & $0.33 \pm 1.22$ & $0.004^{1}$ \\
\hline Height age $(\mathrm{n}=90)$ & Z-score & $-1.27 \pm 1.42$ & $0.30 \pm 1.44$ & $<0.001^{1}$ \\
\hline Head circumference $(\mathrm{n}=90)$ & Z-score & $-0.60 \pm 1.30$ & $0.18 \pm 1.04$ & $0.003^{1}$ \\
\hline C-reactive protein $(\mathrm{n}=79)$ & $\mathrm{mg} / \mathrm{L}$ & $1.0(0.2 ; 2.0)$ & $1.0(1.0 ; 2.6)$ & $0.372^{2}$ \\
\hline Hemoglobin $(\mathrm{n}=75)$ & $\mathrm{g} / \mathrm{dL}$ & $12.1 \pm 1.3$ & $12.0 \pm 0.8$ & $0.747^{1}$ \\
\hline Mean corpuscular volume & $\mathrm{mcm}{ }^{3}$ & $76.0 \pm 6.6$ & $74.7 \pm 4.2$ & $0.315^{1}$ \\
\hline Serum zinc $(\mathrm{n}=78)$ & $\mu \mathrm{g} / \mathrm{dL}$ & $94.0 \pm 23.4$ & $90.3 \pm 18.0$ & $0.450^{1}$ \\
\hline Erythrocyte zinc $(\mathrm{n}=70)$ & $\mu \mathrm{g} / \mathrm{dL}$ & $1413.6 \pm 219.3$ & $1352.1 \pm 267.0$ & $0.358^{1}$ \\
\hline Erythrocyte zinc $(\mathrm{n}=70)$ & $\mu \mathrm{g} / \mathrm{gHb}$ & $119.4 \pm 23.8$ & $112.7 \pm 23.1$ & $0.307^{1}$ \\
\hline Significance level of the t-Student ${ }^{1}$ and Mann-Whitney ${ }^{2}$ tests. & \\
\hline
\end{tabular}

Serum zinc levels $<65 \mu \mathrm{g} / \mathrm{dL}$ and anemia were observed in four (5.1\%) and four (5.3\%) of preterm and term infants, respectively, with no difference between groups (Table 1). No infant had erythrocyte zinc below $40 \mu \mathrm{g} / \mathrm{gHb}$. There was also no statistically significant difference between the preterm and term group in the mean hemoglobin levels $(12.1 \pm 1.3 \mathrm{~g} / \mathrm{dL}$ vs. $12.0 \pm 0.8 \mathrm{~g} / \mathrm{dL} ; \mathrm{p}=0.747)$, red blood cell corpuscular volume $\left(76.0 \pm 6.6 \mathrm{mcm}^{3}\right.$ vs. $\left.74.7 \pm 4.2 \mathrm{mcm}^{3} ; p=0.315\right), \mathrm{CRP}[1.0 \mathrm{mg} / \mathrm{L}(0.2 ; 2.0)$ vs. 1.0 $\mathrm{mg} / \mathrm{L}(1.0 ; 2.6) ; p=0.372]$, serum zinc $(94.0 \pm 23.4 \mu \mathrm{g} / \mathrm{dL}$ vs. $90.3 \pm 18.0 \mu \mathrm{g} / \mathrm{dL} ; \mathrm{p}=0.450)$ and erythrocyte zinc $(119.4 \pm 23.8 \mu \mathrm{g} / \mathrm{gHb}$ vs. $112.7 \pm 23.1 \mu \mathrm{g} / \mathrm{gHb} ; \mathrm{p}=0.307)$ (Table 2$)$.

There was no difference between groups in total daily zinc intake, main meals, and complementary feeding. In turn, we identified a higher intake of total iron, and protein - total and in the main meals (Table 3) - in the non-breastfed preterm group. 
Table 3

Comparison of total daily food consumption of energy, protein, iron, and zinc in the food supplementation and main meals $(n=90)$

\begin{tabular}{|c|c|c|c|c|}
\hline \multirow[t]{2}{*}{ Variables } & \multirow{2}{*}{$\begin{array}{l}\text { Preterm group } \\
(n=43) \\
\begin{array}{l}\text { Breastfed }(n= \\
8)\end{array}\end{array}$} & \multicolumn{2}{|c|}{$\begin{array}{l}\text { Term group } \\
(n=47)\end{array}$} & \multirow[b]{2}{*}{$\begin{array}{l}\text { Non-breastfed (n } \\
=21 \text { ) }\end{array}$} \\
\hline & & $\begin{array}{l}\text { Non-breastfed (n } \\
=33 \text { ) }\end{array}$ & $\begin{array}{l}\text { Breastfed }(n= \\
25)\end{array}$ & \\
\hline \multicolumn{5}{|l|}{ Total } \\
\hline Energy (kcal) & $\begin{array}{l}748.8(417.2 ; \\
932.9)\end{array}$ & $\begin{array}{l}760.7(650.5 ; \\
1128.7)\end{array}$ & $\begin{array}{l}642.9(500.5 \\
763.5)\end{array}$ & $\begin{array}{l}968.9(803.1 ; \\
1246.5)\end{array}$ \\
\hline Energy (kcal/kg) & $\begin{array}{l}78.8(47.5 ; \\
97.1)\end{array}$ & $93.0(77.7 ; 120.4)$ & $60.8(48.1 ; 78.5)$ & $86.7(64.3 ; 124.5)$ \\
\hline Protein (g/kg) & $4.0(1.9 ; 5.1)^{1}$ & $4.3(3.1 ; 5.2)$ & $2.9(1.9 ; 3.2)$ & $4.1(2.9 ; 5.4)$ \\
\hline Iron (mg) & $4.6(1.9 ; 10.9)$ & $10.4(8.7 ; 15.6)^{2}$ & $4.5(2.2 ; 7.3)$ & $8.7(4.3 ; 11.6)$ \\
\hline Zinc (mg) & $4.7(3.0 ; 8.6)$ & $7.6(6.7 ; 11.0)$ & $3.8(2.9 ; 7.3)$ & $7.2(5.4 ; 10.9)$ \\
\hline \multicolumn{5}{|l|}{$\begin{array}{l}\text { Complementary } \\
\text { feeding }\end{array}$} \\
\hline Energy (kcal) & $\begin{array}{l}491.1(316.3 ; \\
720.6)\end{array}$ & $\begin{array}{l}437.3(297.2 \\
788.4)\end{array}$ & $\begin{array}{l}429.0(244.8 \\
636.4)\end{array}$ & $\begin{array}{l}514.8(406.8 \\
802.3)\end{array}$ \\
\hline Energy (kcal/kg) & $\begin{array}{l}63.0(39.4 \\
70.2)\end{array}$ & $57.4(38.3 ; 70.9)$ & $42.9(24.1 ; 54.2)$ & $46.0(30.9 ; 76.7)$ \\
\hline Protein (g/kg) & $2.8(1.8 ; 3.6)^{1}$ & $2.4(1.8 ; 3.3)$ & $1.7(1.2 ; 2.4)$ & $2.6(1.6 ; 3.5)$ \\
\hline Iron (mg) & $3.4(1.8 ; 4.7)$ & $5.9(1.93 ; 11.6)$ & $3.0(1.9 ; 4.6)$ & $3.2(1.9 ; 7.9)$ \\
\hline Zinc (mg) & $2.9(2.2 ; 4.6)$ & $4.2(2.0 ; 8.5)$ & $3.0(1.8 ; 3.8)$ & $3.9(1.8 ; 6.3)$ \\
\hline \multicolumn{5}{|l|}{ Main meals } \\
\hline Energy (kcal) & $\begin{array}{l}275.2(162.0 \\
474.0)\end{array}$ & $\begin{array}{l}219.1(193.4 ; \\
353.8)\end{array}$ & $\begin{array}{l}\text { 196.4 (117.3; } \\
\text { 293.0) }\end{array}$ & $\begin{array}{l}248.9(184.7 \\
393.4)\end{array}$ \\
\hline Energy (kcal/kg) & $\begin{array}{l}35.4(19.7 \\
50.6)^{1}\end{array}$ & $26.9(21.9 ; 36.6)$ & $18.5(11.5 ; 27.6)$ & $23.0(17.0 ; 35.7)$ \\
\hline Protein (g/kg) & $2.4(1.3 ; 3.0)^{1}$ & $1.8(1.3 ; 2.8)$ & $1.4(0.7 ; 2.0)$ & $1.2(1.7 ; 2.7)$ \\
\hline Zinc (mg) & $2.0(1.5 ; 4.2)$ & $1.8(1.2 ; 3.1)$ & $1.8(1.0 ; 2.9)$ & $2.3(1.1 ; 2.8)$ \\
\hline \multicolumn{5}{|c|}{ Significance level of the Mann-Whitney test. } \\
\hline \multicolumn{5}{|c|}{ Preterm group breastfed vs. Term group breastfed $(1 p<0,05)$} \\
\hline
\end{tabular}


The variables independently associated with serum zinc concentrations were breastfeeding at the time of evaluation $(20.11 \mu \mathrm{g} / \mathrm{dL} ; 95 \% \mathrm{Cl} 9.62$ to $30.60 ; \mathrm{p}<0.001)$ and older age (4 to 7 months) of the introduction of food supplementation $(6.6 \mu \mathrm{g} / \mathrm{dL} ; 95 \% \mathrm{Cl} 5.3-11.4 ; \mathrm{p}<0.001)$. Breastfeeding was independently and directly associated with its erythrocyte zinc levels $(18.8 \mathrm{ug} / \mathrm{dL} ; 95 \% \mathrm{Cl} 3.7$ to $33.8 ; \mathrm{p}=$ 0.015) (Table 4). 
Table 4

Factors associated with the levels of serum and erythrocyte zinc in infants

\begin{tabular}{|c|c|c|c|c|c|c|}
\hline \multirow{2}{*}{$\begin{array}{l}\text { Dependent variable } \\
\text { Serum zinc }(\mu \mathrm{g} / \mathrm{dL})^{1}\end{array}$} & \multirow{2}{*}{$\begin{array}{l}\text { Predictors } \\
\text { Age (months) }\end{array}$} & \multirow{2}{*}{$\begin{array}{l}R^{2} \\
0.409\end{array}$} & \multirow{2}{*}{$\begin{array}{l}\text { B } \\
0.11\end{array}$} & \multicolumn{2}{|c|}{$\begin{array}{l}95 \% \text { confidence } \\
\text { interval }\end{array}$} & \multirow{2}{*}{$\begin{array}{l}\text { P- } \\
\text { value }\end{array}$} \\
\hline & & & & -0.95 & 1.18 & \\
\hline \multirow[t]{10}{*}{$(n=70)$} & Gender (male) & & 0.47 & -8.61 & 9.56 & 0.917 \\
\hline & Group (preterm) & & 6.20 & -5.19 & 17.60 & 0.280 \\
\hline & Zinc intake (mg) & & 0.31 & -0.74 & 1.37 & 0.559 \\
\hline & BMI Z-score & & 1.31 & -3.13 & 5.76 & 0.556 \\
\hline & Height Z-score/age & & 3.16 & -0.20 & 6.53 & 0.065 \\
\hline & C-reactive protein (mg/L) & & -0.88 & -2.02 & 0.25 & 0.127 \\
\hline & Breastfeeding (yes) & & 20.11 & 9.62 & 30.60 & 0.000 \\
\hline & Infant formula (yes) & & 3.26 & -10.63 & 17.17 & 0.640 \\
\hline & Whole cow's milk (yes) & & -6.86 & -20.24 & 6.50 & 0.308 \\
\hline & $\begin{array}{l}\text { Complementary feeding ons } \\
\text { (months) }\end{array}$ & & 6.63 & 3.72 & 9.55 & 0.000 \\
\hline $\begin{array}{l}\text { Erythrocyte zinc } \\
(\mathrm{ug} / \mathrm{gHb})\end{array}$ & Age (months) & 0.268 & 0.65 & -1.096 & 2.39 & 0.457 \\
\hline \multirow[t]{10}{*}{$(n=55)$} & Gender (male) & & 3.86 & -10.127 & 17.86 & 0.580 \\
\hline & Group (preterm) & & 14.20 & -3.583 & 31.99 & 0.115 \\
\hline & Zinc intake (mg) & & 0.97 & -0.493 & 2.44 & 0.188 \\
\hline & BMI Z-score & & 1.78 & -4.552 & 8.11 & 0.574 \\
\hline & Height Z-score/age & & -2.03 & -7.260 & 3.19 & 0.438 \\
\hline & C-reactive protein (mg/L) & & 0.92 & -0.675 & 2.51 & 0.251 \\
\hline & Breastfeeding (yes) & & 18.83 & 3.782 & 33.88 & 0.015 \\
\hline & Infant formula (yes) & & -12.96 & -33.367 & 7.44 & 0.207 \\
\hline & Whole cow's milk (yes) & & -17.22 & -37.637 & 3.18 & 0.096 \\
\hline & $\begin{array}{l}\text { Complementary feeding ons } \\
\text { (months) }\end{array}$ & & -1.41 & -5.619 & 2.80 & 0.503 \\
\hline
\end{tabular}

\section{Discussion}


This study found no difference regarding blood concentrations and dietary zinc intake between preterm and term infants. Serum and erythrocyte zinc levels were influenced by breastfeeding and time of complementary feeding introduction. Preterm infants had worse anthropometric indicators than term infants.

There are no well-defined cutoff points for serum and erythrocyte zinc concentrations in healthy and preterm infants. Study realized with 27,801 individuals, aged between 6 months and 74 years, suggested that values below $65 \mu \mathrm{g} / \mathrm{dL}$ (2.5th percentile) of serum zinc could be considered low for children under ten years of age [26]. However, the authors did not propose specific cutoff points for infants, nor did they relate these inappropriate values to relevant clinical outcomes. In this study, using the same cutoff point, the prevalence of serum zinc deficiency was less than $5 \%$ and was not more frequent in preterm infants, nor was it associated with malnutrition and short stature.

Preterm newborns have lower serum zinc levels than term infants in the first months of life, and in this group, enteral zinc supplementation during hospitalization is associated with reduced mortality, improved weight gain, and linear growth up to two years of age [27]. This difference in serum zinc levels between preterm and term infants decreases over time and can disappear at around 9 to 12 months corrected age $[11,12-15]$.

Studies that evaluated serum zinc levels and the effects of supplementation in clinical outcomes such as growth $[7,14-15]$ and development $[13,16,28]$ in preterm infants in the follow-up after hospital discharge show divergent results [29]. Differently from our study, these publications included moderate or late preterm infants with younger age and lower breastfeeding rates.

Serum and erythrocyte zinc levels were higher in breastfed infants at the time of evaluation. This finding is similar to that of Waunen et al., 1999 [14], who found higher zinc concentrations in the hair of breastfed preterm and term infants at 6 and 12 months corrected age. However, it differs from other studies with term infants who find lower zinc concentrations in breastfed infants than those receiving infant formulas [30, 31].

The zinc content in human milk varies considerably $(0.7$ to $1.6 \mathrm{mg} / \mathrm{L})$ and decreases with the time of lactation. Colostrum, human milk at seven and thirty days of life, contains $8-12 \mathrm{mg} / \mathrm{L}, 3-6 \mathrm{mg} / \mathrm{L}$, and 1$3 \mathrm{mg} / \mathrm{L}$ of zinc, respectively [32]. Despite this progressive reduction and lower content [32, 33], the bioavailability of zinc in human milk is always greater than in infant formulas $(60 \%$ vs. $24 \%)[14,35]$.

Besides the better bioavailability of zinc in human milk, two other factors may justify the association of breastfeeding with better blood concentrations of zinc in this study. Breastfed children tend to have adequate time of introduction, quality, and variety of the foods offered during complementary feeding [36]; and a lower frequency of infectious conditions that lead to more significant zinc depletion, such as diarrheal and respiratory disease [37]. 
In this study, the introduction of complementary feeding in the preterm group agreed with the current recommendations ( 5 to 8 months of chronological age age) and was associated with higher levels of serum zinc in both groups. The early introduction of solid foods (before three months corrected age or five months chronological age), food supply with low density of energy and micronutrients are common problems in the complementary feeding in preterm infants and they are associated with nutritional disorders [37-40].

A quarter of the preterm infants evaluated were of short stature, and $10 \%$ were malnourished according to anthropometric indicators for corrected age. This nutritional impairment was not associated with worse zinc concentrations, which can be justified because this group has a high percentage of extremely low birth weight and small for gestational age children with a prolonged median length of stay (two months), factors that are associated with worse postnatal growth and longer time for nutritional recovery [41]. Preterm children may take two to eight years to normalize their anthropometric indicators, and the longitudinal monitoring of these measurements helps differentiate between catch-up growth and nutritional impairment.

In general, there were no significant differences in dietary intake between the preterm and term groups. On the other hand, we observed low breastfeeding rates, especially among preterm children, early introduction of cow's milk, and low adherence to prophylactic iron supplementation in both groups. This set of factors puts this population at risk for nutritional excess and deficiencies, partially explaining the percentage of infants with anemia (10\%) and overweight $(6.4 \%)$ in young infants.

The repercussions of inappropriate dietary practices can be more intense on the health of preterm infants. The improvement of this knowledge, the inclusion of specific recommendations, and differentiated intervention proposals can modify these children's growth, development, and global health in the short and long term aspects [42].

The strengths of this study can be considered the presence of a comparison group from the same city, with socio-economic and cultural characteristics similar to the study group, the detailed of the dietary intake of infants, and the measurement of serum and erythrocyte zinc, which are markers of acute and chronic deficiency of this micronutrient, respectively. On the other hand, limitations can be considered the impossibility of calculating dietary intake in breastfed infants, the absence of other zinc biomarkers such as metallothioneins, and the non-systematic collection of information about diseases developed by the group of preterm infants after hospital discharge.

\section{Conclusions}

In conclusion, the findings of this study did not show that the nutritional status concerning zinc was worse in a group of preterm infants compared to term infants during complementary feeding. In turn, regardless of prematurity, levels of serum and erythrocyte zinc were influenced by breastfeeding and onset of complementary feeding. 


\section{List Of Abbreviations}

WHO (World Health Organization)

SGA (small for gestational age)

AGA (adequate for gestational age)

LGA (large for gestational age)

BMIZ (body mass index score z)

HAZ (height for age score $z$ )

HCZ (head circumference for age score $z$ )

CRP (C reative protein)

ICP-MS (coupled plasma mass spectrometry method)

\section{Declarations}

\section{Ethics approval and consent to participate:}

The Research Ethics Committee of Universidade Federal de São Paulo approved the study under Opinion $N^{\circ}$ 2.937.127 and we confirm that all methods were perfomed in accordance with the Declaration of Helsinki. The children's legal guardians signed the informed consent form after the interview and clarifications by the researchers regarding the study's steps and procedures.

\section{Consent for publication:}

Not applicable

\section{Availability of data and materials:}

The datasets used and/or analysed during the current study are available from the corresponding author on reasonable request.

\section{Competing interests:}

The authors declare that they have no competing interests 


\section{Funding:}

FAPESP - Fundação de Amparo a Pesquisa do Estado de São Paulo Number: 2016/09428-1

\section{Authors' contributions:}

TRAS (design of the work, acquisition analysis, interpretation data, draft the work), ACPV (design of the work, acquisition analysis, interpretation data, draft the work), FLAF (acquisition analysis, interpretation data, draft the work), CWL (acquisition analysis, interpretation data), MWLS (acquisition analysis, interpretation data), ROSS (acquisition analysis, interpretation data), FISS (conception and design of the work, acquisition analysis, interpretation data, draft the work, revision and submission). All authors approved the submitted version.

\section{Acknowledgements:}

Multidisciplinary team of Hospital Municipal de São Bernardo do Campo and Primary Health Care Team of UBS Vila Euclides.

\section{References}

1. Schibba I, Ogden K, Smith M, Heneghan E, Terki F, Stevens B. Unlocking the Hidden Hunger Crises: The Power of Public-Private Partnerships. World Rev Nutr Diet. 2020;121:16-20.

2. Freeland-Graves JH, Sachdev PK, Binderberger AZ, Sosanya ME. Global diversity of dietary intakes and standards for zinc, iron, and copper. J Trace Elem Med Biol. 2020;61:126515.

3. Chasapis CT, Ntoupa PA, Spiliopoulou CA, Stefanidou ME. Recent aspects of the effects of zinc on human health. Arch Toxicol. 2020;94:1443-1460.

4. de Benoist B, Darnton-Hill I, Davidsson L, Fontaine O, Hotz C. Conclusions of the Joint WHO/UNICEF/IAEA/IZiNCG Interagency Meeting on Zinc Status Indicators. Food Nutr Bull. 2007;28:S480-4.

5. Gupta S, Brazier AKM, Lowe NM. Zinc deficiency in low- and middle-income countries: prevalence and approaches for mitigation. J Hum Nutr Diet. 2020;33:624-643.

6. Lassi ZS, Kurji J, Oliveira CS, Moin A, Bhutta ZA. Zinc supplementation for the promotion of growth and prevention of infections in infants less than six months of age. Cochrane Database Syst Rev. 2020;4:CD010205.

7. Mayo-Wilson E, Junior JA, Imdad A, Dean S, Chan XH, Chan ES, et al. Zinc supplementation for preventing mortality, morbidity, and growth failure in children aged 6 months to 12 years of age. Cochrane Database Syst Rev. 2014;5:CD009384. 
8. Terrin G, Berni-Canani R, Di Chiara M, Pietravalle A, Aleandri V, Conte F, et al. Zinc in Early Life: A Key Element in the Fetus and Preterm Neonate. Nutrients. 2015;7:10427-46.

9. Gulani A, Bhatnagar S, Sachdev HP. Neonatal zinc supplementation for prevention of mortality and morbidity in breastfed low birth weight infants: systematic review of randomized controlled trials. Indian Pediatr. 2011;48:111-7.

10. Harris T, Gardner F, Podany A, Kelleher SL, Doheny KK. Increased early enteral zinc intake improves weight gain in hospitalised preterm infants. Acta Paediatr. 2019;108:1978-1984.

11. Terrin G, Berni-Canani R, Passariello A, Messina F, Conti MG, Caoci S, et al. Zinc supplementation reduces morbidity and mortality in very-low-birth-weight preterm neonates: a hospital-based randomized, placebo-controlled trial in an industrialized country. Am J Clin Nutr. 2013;98:1468-74.

12. Sazawal S, Black RE, Menon VP, Dinghra P, Caulfield LE, Dhingra U, et al. Zinc supplementation in infants born small for gestational age reduces mortality: a prospective, randomized, controlled trial. 2001;108:1280-6.

13. Cho JM, Kim JY, Yang HR. Effects of oral zinc supplementation on zinc status and catch-up growth during the first 2 years of life in children with non-organic failure to thrive born preterm and at term. Pediatr Neonatol. 2019;60:201-209.

14. Wauben I, Gibson R, Atkinson S. Premature infants fed mothers' milk to 6 months corrected age demonstrate adequate growth and zinc status in the first year. Early Hum Dev. 1999;54:181-94.

15. Díaz-Gómez NM, Doménech E, Barroso F, Castells S, Cortabarria C, Jiménez A. The effect of zinc supplementation on linear growth, body composition, and growth factors in preterm infants. 2003;111:1002-9.

16. Mathur NB, Agarwal DK. Zinc Supplementation in Preterm Neonates and Neurological Development, A Randomized Controlled Trial. Indian Pediatr. 2015;52:951-5.

17. Ballard JL, Khoury JC, Wedig K, Wang L, Eilers-Walsman BL, Lipp R. New Ballard Score, expanded to include extremely premature infants. J Pediatr. 1991;119:417-23.

18. Villar J, Cheikh Ismail L, Victora CG, Ohuma EO, Bertino E, et al; International Fetal and Newborn Growth Consortium for the 21st Century (INTERGROWTH-21st). International standards for newborn weight, length, and head circumference by gestational age and sex: the Newborn Cross-Sectional Study of the INTERGROWTH-21st Project. 2014;384:857-68.

19. WHO Expert Committee on Physical Status : the Use and Interpretation of Anthropometry (1993: Geneva, Switzerland) \& World Health Organization. (1995). Physical status: the use of and interpretation of anthropometry, report of a WHO expert committee. World Health Organization. https://apps.who.int/iris/handle/10665/37003

20. de Onis M, Garza C, Victora CG, Onyango AW, Frongillo EA, Martines J. The WHO Multicentre Growth Reference Study: planning, study design, and methodology. Food Nutr Bull. 2004;25:S15-26.

21. United States Department of Agriculture (USDA). Agricultural Research Service. USDA National nutrient database for standard reference. 
22. Tabela Brasileira de Composição de Alimentos (TACO) / NEPA-UNICAMP- Versão II. 3a ed. Campinas, SP: NEPA-UNICAMP, 2006.

23. Ministry of Health. Secretariat of Primary Health Care. Department of Health Promotion. Food Guide for Brazilian children under 2 years. 2019.

24. World Health Organization. Nutritional anaemias: tools for effective prevention and control. WHO Document Production Services, Geneva, Switzerland, 2017.

25. Gibson RS, Hess SY, Hotz C, Brown KH. Indicators of zinc status at the population level: a review of the evidence. Br J Nutr. 2008;3:S14-23.

26. Hotz C, Peerson JM, Brown KH. Suggested lower cutoffs of serum zinc concentrations for assessing zinc status: reanalysis of the second National Health and Nutrition Examination Survey data (19761980). Am J Clin Nutr. 2003;78:756-64.

27. Staub E, Evers K, Askie LM. Enteral zinc supplementation for prevention of morbidity and mortality in preterm neonates. Cochrane Database Syst Rev. 2021 12;3:CD012797.

28. Black MM, Sazawal S, Black RE, Khosla S, Kumar J, Menon V. Cognitive and motor development among small-for-gestational-age infants: impact of zinc supplementation, birth weight, and caregiving practices. 2004;113:1297-305.

29. Griffın IJ, Domellöf M, Bhatia J, Anderson DM, Kler N. Zinc and copper requirements in preterm infants: an examination of the current literature. Early Hum Dev. 2013;89:S29-34.

30. Sezer RG, Aydemir G, Akcan AB, Bayoglu DS, Guran T, Bozaykut A. Effect of breastfeeding on serum zinc levels and growth in healthy infants. Breastfeed Med. 2013;8:159-63.

31. Dumrongwongsiri O, Suthutvoravut U, Chatvutinun S, Phoonlabdacha P, Sangcakul A, Siripinyanond A, et al. Maternal zinc status is associated with breast milk zinc concentration and zinc status in breastfed infants aged 4-6 months. Asia Pac J Clin Nutr. 2015;24:273-80.

32. Terrin G, Boscarino G, Di Chiara M, lacobelli S, Faccioli F, Greco C, et al. Nutritional Intake Influences Zinc Levels in Preterm Newborns: An Observational Study. Nutrients. 2020;12:529.

33. Sabatier M, Garcia-Rodenas CL, Castro CA, Kastenmayer P, Vigo M, Dubascoux S, et al. Longitudinal Changes of Mineral Concentrations in Preterm and Term Human Milk from Lactating Swiss Women. Nutrients. 2019;11:1855.

34. Trinta VO, Padilha PC, Petronilho S, Santelli RE, Braz BF, Freire AS, et al. Total metal content and chemical speciation analysis of iron, copper, zinc and iodine in human breast milk using highperformance liquid chromatography separation and inductively coupled plasma mass spectrometry detection. Food Chem. 2020;326:126978.

35. World Health Organization (1996) Trace elements in human nutrition and health. Report of WHO Expert Committee. WHO, Geneva.

36. Spaniol AM, da Costa THM, Bortolini GA, Gubert MB. Breastfeeding reduces ultra-processed foods and sweetened beverages consumption among children under two years old. BMC Public Health. 2020;20:330. 
37. Victora CG, Rollins NC, Murch S, Krasevec J, Bahl R. Breastfeeding in the 21st century - Authors' reply. 2016;387:2089-2090.

38. Fanaro S, Borsari G, Vigi V. Complementary feeding practices in preterm infants: an observational study in a cohort of Italian infants. J Pediatr Gastroenterol Nutr. 2007;45:S210-4.

39. Ribas SA, de Rodrigues MCC, Mocellin MC, Marques ES, da Rosa GPC, Maganha CR. Quality of complementary feeding and its effect on nutritional status in preterm infants: a cross-sectional study. J Hum Nutr Diet. 2020 Apr 26.

40. Crippa BL, Morniroli D, Baldassarre ME, Consales A, Vizzari G, Colombo L, et al. Preterm's Nutrition from Hospital to Solid Foods: Are We Still Navigating by Sight? Nutrients. 2020;12:3646.

41. Giuliani F, Cheikh Ismail L, Bertino E, Bhutta ZA, Ohuma EO, Rovelli I, et al. Monitoring postnatal growth of preterm infants: present and future. Am J Clin Nutr. 2016;103:635S-47S.

42. Ong KK, Kennedy K, Castañeda-Gutiérrez E, Forsyth S, Godfrey KM, Koletzko B, et al. Postnatal growth in preterm infants and later health outcomes: a systematic review. Acta Paediatr. 2015;104:974-86. 